\title{
Survival Strategies of Indonesian Immigrants in Kota Kinabalu, Sabah, Malaysia
}

\author{
Dzurizah Ibrahim, Jalihah Md Shah, and Rose Patsy Tibok \\ Faculty of Humanities, Arts \& Heritage, University Malaysia Sabah \\ Correspondence: Dzurizah Ibrahim (email: idzuri@ums.edu.my)
}

\begin{abstract}
Findings of studies on the presence of immigrant workers in Malaysia often present negative social and economic implications. Their entry into the country is frequently a contentious issue due to their presence associated often with illegal foreign workers. This paper however is an attempt to provide insights into the involvement of Indonesian immigrants in the food business sector, their business adaptability and their survival strategies in a foreign land. The Indonesian immigrants' experiences, from their beginnings in Sabah until their current social and community achievements, are presented in this study. Anchored on a biography study orientation and the in-depth interview method, this exploratory study examines the life experiences of five food business entrepreneurs in Kota Kinabalu, Sabah using the snowball effect as a sampling method with the subsequent data analysed thematically. Findings indicate determination and dedication as the main threads in the positive survival among Indonesian food business entrepreneurs. This study identifies seven survival strategies instrumental to the success and adaptability of the Indonesian immigrant community in their host country. Based on the findings, it can be concluded that (1) not all immigrants become liabilities to their host country and community, (2) some immigrants develop local communities by building public religious schools, and (3) some immigrants contribute to the development of local economies. The findings from this study can be utilised to develop better and more positive social and economic development overtures that could sustain a harmonious and peaceful society.
\end{abstract}

Keywords: immigrants; entrepreneurs; Sabah; survival; workers

\section{Introduction}

Numerous studies on immigrant workers in Malaysia have associated this group with negative or unsavoury social and economic implications (Ramli et al., 2006; Dzurizah \& Jalihah, 2006; Jalihah \& Ubong, 2006). The presence of these workers is often a contentious issue since the common perception among the local community is of them as illegals and in their host country by dubious means (Dayang Suria, 2009; $\mathrm{Hj}$. Light, 2004). This paper however does not focus on this issue of legality and instead is an attempt to examine the Indonesian immigrant phenomenon from the perspective of their involvement in the food industry that has ensured their survival in their adopted home.

In Malaysia, various research have been conducted pertaining to the involvement of foreign workers as economic contributors in the agriculture, construction, fisheries or other 
informal sectors (Ho Ting Seng, 1989; Zulkifly, 1989; Azizah, 2004; Ismail, 2008; Dayang Suria, 2009; Dzurizah \& Jalihah, 2014). A study on the acculturation experience and process of cultural adaptation among Filipino immigrants in Sabah by Halina (2003) highlights four critical elements: (1) the group is observed to be inclined towards integrating local cultures and norms while being steadfast in their own traditions, (2) linguistic ability or competency has a critical role in ensuring the acculturation behaviour, (3) knowledge of culture, perception towards that culture and personal relationships generated with the local communitry assist in the acculturation process, and (4) all these aspects are interrelated in determining the ease of acculturation among immigrants. The findings of this study point to acculturation into the local culture as key in the survival strategies of Filipino immigrants in Sabah with the element of communication singled out as a key aspect for successful integration. This situation could be better elaborated by examining other elements that might influence or determine the survival strategies of immigrants in their host countries. Such is the premise of this paper.
In addition to Filipino immigrants, Sabah is also a popular destination for Indonesian workers. A total of 260, 000 Indonesian immigrant labour was documented by the Indonesian Consulate in Sabah in 2015 (Ramli \& Mohd. Kamarulnizam, 2015) in comparison to the 313,652 that officially registered with the Indonesian Consulate in June 2011 (Konsulat Indonesia Sabah, 2011). Although this figure shows a decrease in the overall number of Indonesian workers in Sabah, a point to be noted here is that 141,033 from this total are employed in the agriculture or farming industry (Daud, 2004; James, 2004; Yap Pak Leong, 2004). Only 7,805 work in the service industry with 1,299 employed in restaurants as cooks, kitchen assistants and waiters (Konsulat Indonesia Sabah, 2011).

\section{Methodology}

This study is an attempt to explore the lives and livelihood of the Indonesian immigrant community involved in food business. Five food business entrepreneurs located in Kota Kinabalu were chosen as the focus of

Table 1 Background of Respondents

\begin{tabular}{|c|c|c|c|c|c|c|}
\hline Name & $\begin{array}{l}\text { Year of } \\
\text { entry } \\
\text { into } \\
\text { Sabah }\end{array}$ & $\begin{array}{l}\text { Current } \\
\text { age }\end{array}$ & Origin & $\begin{array}{c}\text { Family } \\
\text { background } \\
\text { in Indonesia }\end{array}$ & $\begin{array}{l}\text { No. of } \\
\text { children }\end{array}$ & $\begin{array}{l}\text { Business } \\
\text { role model }\end{array}$ \\
\hline Pak Yanto & 1986 & 45 & $\begin{array}{l}\text { Malang, } \\
\text { East Java }\end{array}$ & Farmer & 3 & $\begin{array}{l}\text { Chinese } \\
\text { traders }\end{array}$ \\
\hline Ibu Indang & 1979 & 56 & Central Java & Cloth Trader & 3 & Pak Mokti \\
\hline Pak Rosli & 1980 & 48 & $\begin{array}{l}\text { Malang, } \\
\text { East Java }\end{array}$ & Farmer & 3 & $\begin{array}{l}\text { Chinese } \\
\text { traders }\end{array}$ \\
\hline Pak Ismail & 1989 & 42 & $\begin{array}{l}\text { Banyuwangi, } \\
\text { East Java }\end{array}$ & Farmer & 3 & Pak Mokti \\
\hline Pak Mokti & $1970 s$ & 61 & $\begin{array}{l}\text { Magelang, } \\
\text { Central Java }\end{array}$ & $\begin{array}{l}\text { Teacher/ } \\
\text { Farmer }\end{array}$ & 5 & - \\
\hline
\end{tabular}


this exploratory study utilising the snowball effect. Based on biography study, this paper examined the life experiences and survival strategies of these five individuals from the time of their entry into Sabah until their current achievements. Data was analysed using the thematic analysis method.

In the discussion on the trials and tribulations of forging a living through the food business in Kota Kinabalu, the study found that all five respondents originated from the Indonesian island of Java. Table 1 summarises the background of the respondents.

\section{Findings and Discussion}

The respondents migrated to Sabah when they were in their twenties motivated by interest and economic pull factors. The in-depth interviews and thematic analysis revealed seven survival strategies prevalent among the five respondents: acquisition of capital, employment relationships, skills, citizenship status quo, positive and collective values, networking, and courage and commitment. These are discussed in the subsequent sections.

Table 2 Current Status of Business

\begin{tabular}{|c|c|c|c|c|c|}
\hline Name & $\begin{array}{l}\text { Previous } \\
\text { work }\end{array}$ & $\begin{array}{l}\text { Year of business } \\
\text { start- up }\end{array}$ & $\begin{array}{c}\text { Current } \\
\text { ownership } \\
\text { status }\end{array}$ & $\begin{array}{c}\text { Current } \\
\text { business } \\
\text { capital and } \\
\text { source }\end{array}$ & $\begin{array}{c}\text { No. of } \\
\text { workers }\end{array}$ \\
\hline Pak Yanto & $\begin{array}{l}\text { Working in } \\
\text { a 'warung } \\
\text { tumpang' }\end{array}$ & $\begin{array}{c}1999 \text { (Warung } \\
\text { tumpang) } \\
\text { Capital: RM5,000 } \\
\text { (Savings) }\end{array}$ & $\begin{array}{l}2 \text { restaurants } \\
\text { (Rented) }\end{array}$ & $\begin{array}{l}\text { RM80,000 } \\
\text { (Own } \\
\text { savings) }\end{array}$ & 6 \\
\hline Ibu Indang & $\begin{array}{l}\text { Following } \\
\text { husband }\end{array}$ & $\begin{array}{l}1995 \text { (Restaurant) } \\
\text { Capital: } \\
\text { RM50,000 (Bank } \\
\text { loan) }\end{array}$ & $\begin{array}{l}1 \text { 'warung } \\
\text { tumpang' } \\
\text { (Rented) }\end{array}$ & $\begin{array}{l}\text { RM1,500 } \\
\text { (Savings) }\end{array}$ & 4 \\
\hline Pak Rosli & $\begin{array}{l}\text { Working } \\
\text { in a } \\
\text { restaurant }\end{array}$ & $\begin{array}{l}1995 \text { (Warung } \\
\text { tumpang) } \\
\text { Capital: RM5,000 } \\
\text { (Savings from } \\
\text { salary) }\end{array}$ & $\begin{array}{l}2 \text { restaurants } \\
\text { (Rented) }\end{array}$ & $\begin{array}{l}\text { RM40,000 } \\
\text { (Savings and } \\
\text { loans from } \\
\text { friends) }\end{array}$ & 16 \\
\hline Pak Ismail & $\begin{array}{l}\text { Working in } \\
\text { a furniture } \\
\text { shop }\end{array}$ & $\begin{array}{c}1990 \text { (Mobile } \\
\text { stall) } \\
\text { Capital: RM2,000 } \\
\text { (Savings) }\end{array}$ & $\begin{array}{c}1 \text { restaurant } \\
\text { (Rented) and } 5 \\
\text { mobile stall }\end{array}$ & $\begin{array}{l}\text { RM50,000 } \\
\text { (Savings) }\end{array}$ & 15 \\
\hline Pak Mokti & $\begin{array}{l}\text { Religious } \\
\text { preacher }\end{array}$ & $\begin{array}{c}1980 \text { (Cake } \\
\text { vendor) } \\
\text { Capital: RM50 }\end{array}$ & $\begin{array}{c}4 \text { restaurants } \\
\text { (Self- owned), } \\
\text { catering, training } \\
\text { consultancy } \\
\text { and real estate } \\
\text { business }\end{array}$ & $\begin{array}{c}\text { RM1 million } \\
\text { (Bank } \\
\text { overdraft) }\end{array}$ & 150 \\
\hline
\end{tabular}




\section{Acquisition of Capital}

\section{Savings}

Savings accumulated over many years of hard work was used as start- up capital for the respondents' food business venture. For Pak Yanto, accumulating the necessary amount had meant continuous work and years of prudent spending and sacrifice for both him and his wife. This purpose- driven attitude and sheer hard work enabled them to start their food business with the cash purchase of their restaurant for $\mathrm{RM} 80,000$, their entire amount of savings they had began from 1991.

It was a similar scenario for Pak Rosli, Pak Ismail and Pak Mokti whose early days in Sabah were fraught with challenges and setbacks. It was also through a combination of personal grit and unending hard work that made it possible for them to save the capital needed to embark on their food business venture. It was this determination to work non- stop that prevented the three men from visiting their relatives in Indonesia for many years. Pak Ismail began a 'warung tumpang' business with a start- up capital of RM2, 000 from both his and his wife's savings. When they wanted to expand this stall business into a restaurant, the RM50,000 capital was obtained from savings accumulated from years of mobile vendor enterprise. Table 2 reports on the current status of business for the five respondents.

\section{Loan from Bank/Friends}

Loans from banks or fellow Indonesian were another source of capital acquisition for the respondents. One of them in fact managed to secure a RM50,000 bank loan to use as business capital (with the repayment rate at RM800 per month). Pak Yanto obtained an amount of RM20, 000 from a bank re-financing of a fully- paid vehicle of a friend. This amount, at a monthly repayment rate of RM450, enabled him to expand his food business and pay the RM2, 500 monthly rental.

For the mobile food vendor business of Pak Ismail, his decision to upgrade from bicycle to motorcycle required the use of his own savings. However, when his subsequent business expansion plans necessitated the use of a van, Pak Ismail sought and obtained a bank loan of RM24, 000 at the repayment rate of RM400 per month.

From this, it becomes evident that the acquisition of capital was critical as a starting point in initiating change and success in the lives of the respondents in their adopted country. Without the resolve, commitment and tenacity in ensuring that a sizeable portion of their earnings was set aside or the courage to take risks and seek loans, their food business venture would not have been possible.

\section{Employment Relationship}

This section discusses how the respondents viewed the aspect of employment relationship through their perception of their workers, the type of employment relationship practised, and the work facilities they provided as the business owners and employers.

\section{Perception of Workers}

The relationship between employer and workers is critical in that it determines the employment relationship direction that the organisation wishes to establish. Table 3 illustrates the method which the respondents applied when recruiting foreign workers and the majority of workers in their food business premises. 
Table 3 Worker Recruitment Method and Worker Majority

\begin{tabular}{lcc}
\hline Employer & Worker Recruitment Method & Workers \\
\hline Pak Yanto & Semi- official \& unofficial & Javanese majority \\
Ibu Indang & Unofficial & Javanese, Filipino and local \\
Pak Rosli & Semi- official \& unofficial & Javanese majority \\
Pak Ismail & Semi- official \& unofficial & Javanese majority \\
Pak Mokti & Official, semi- official \& unofficial & Javanese majority \\
\hline
\end{tabular}

For Pak Yanto, the choice of Javanese workers was based on his perception of them as being trustworthy. This was due to not only himself being Javanese but also because the workers came from his Javanese village or district. The similarity of language and culture was therefore seen as a completion to the business that he was building up. As shared by Pak Yanto, any worker- related problem or issue could be easily addressed since "anyone who runs away, we will go look for them in the village... (in Java)... we know the father". He was once cheated by Filipino workers which made him wary of other races or nationalities. The daily earnings of the restaurant were often pilfered by these workers which resulted in him incurring significant losses. Pak Yanto also faced problems of workers constantly asking for loans.

This perception was shared by Pak Ismail who viewed Javanese workers as being more trustworthy than their local counterparts. According to him, "it is easier to manage Javanese workers compared to local ones who do not want to put in extra work". Pak Ismail had more confidence in the ability of his Javanese workers to fully manage the five vans in his mobile vendor business. For lbu Indang, although her workers consisted of mostly locals, their tendency to borrow money or ask for advance pay even when they had worked for less than a month was a source of irritant for her. Local workers also had a habit of applying for leave or days off which affected the smooth running of her food business.
Pak Mokti and Pak Rosli held similar perceptions of Javanese workers as dependable and trustworthy. However, although both were more inclined towards these workers, they still saw to the needs and interests of their other employees. The high turnover rate among restaurant workers was also seen as a challenge to food business owners. There was a high premium on experienced staff, and this category of workers needed to be retained to cut costs. A system of control was therefore put in place to avoid any problem that could arise from the high worker turnover rate. Pak Mokti admitted that "my workers are many, constantly changing except for a few who have been with me for a long time... they help me control the constant flow of new workers... I do not want my workers to quarrel or to have romantic liasons...".

\section{Employer-Worker Relationship Boundaries}

Based on their perceived notions of their workers, the respondents were observed to have established certain boundaries to regulate the relationship or interaction between employer and staff. Table 4 demonstrates for instance Pak Yanto's cautious approach towards his workers, impacted in part by his past experience of being cheated by them. This was in contrast to Ibu Indang and Pak Mokti who practised a more friendly approach and viewed their workers as their own family members. Pak Ismail and Pak Rosli voiced 
Table 4 Employer-Worker Relationship Boundaries

\begin{tabular}{ll}
\hline Employer & Employer-Worker Relationship Boundaries \\
\hline Pak Yanto & Cautious: \\
& Low trust in workers \\
Ibu Indang & Family- oriented: \\
& Workers viewed as family \\
Pak Rosli & Friendly: \\
& Workers treated as friends to facilitate work and business \\
Pak Ismail & Trusting: \\
& Workers trusted to manage and operate mobile stall business \\
Pak Mokti & Friendly but Controlled: \\
& Employer has to be friendly with workers but be in control to \\
& minimise problems
\end{tabular}

the need to approach workers as friends. However, Pak Mokti shared that control was necessary to manage staff especially new workers whereby the very survival of his food business depended on the quality and productivity of food and service extended to customers. Table 4 presents the employerworker boundaries practised by the five respondents in their businesses.

\section{Facilities for Workers}

The respondents provided basic facilities for their workers. For instance, since the businesses were food-based, the workers would usually benefit from free meals. All the respondents also provided basic accommodation, transport and prayer room facilities at the workplace. To safeguard the welfare of his staff, workers under Pak Mokti were provided insurance coverage and registered into both Pertubuhan Keselamatan Sosial (PERKESO) and Kumpulan Wang Simpanan Pekerja (KWSP), a governmentregulated retirement fund whereby employer contribution based on worker salary is required. Table 5 illustrates the facilities and benefits provided by the respondents for their workers.

Employment relationship is seen as an important aspect towards strengthening and increasing both worker and organisational productivity (Blyton \& Turnbull, 2004). This study found that the respondents placed priority on this aspect to ensure the sustainability and survival of the food business they had built from the very beginning. Workers form the most critical asset in any organisation and as employers, the

\section{Table 5 Facilities Provided for Workers}

\begin{tabular}{lccc}
\hline Employer & $\begin{array}{c}\text { Worker } \\
\text { accommodation }\end{array}$ & Prayer room facilities & Food \\
\hline Pak Yanto & $\sqrt{ }$ & $\sqrt{ }$ & $\sqrt{ }$ \\
lbu Indang & $\sqrt{ }$ & - & $\sqrt{ }$ \\
Pak Rosli & $\sqrt{ }$ & $\sqrt{ }$ & $\sqrt{ }$ \\
Pak Ismail & $\sqrt{ }$ & $\sqrt{ }$ & $\sqrt{ }$ \\
Pak Mokti & $\sqrt{ }$ & $\sqrt{ }$ & $\sqrt{ }$ \\
\hline
\end{tabular}


respondents were aware of the importance of fostering positive employer-worker relationships and providing basic facilities to cater to their dayto-day convenience.

Apart from this, to ensure the survival of Indonesian immigrants engaged in food business in Sabah, the quality of food provided in the restaurant establishments is focused on. This is discussed in detail in the following section.

\section{Cooking Skills}

Survival in the food business sector requires the food to be consistent in quality and standard. A quality control or monitoring mechanism therefore needs to be implemented to ensure the output fulfils the set or expected standard. For this purpose, Pak Mokti established a central kitchen to produce and supply all the core ingredients and pastes for main menu items on offer in his four restaurants. A single producer or supplier ensures that food taste and quality is consistent regardless of restaurant location. However, food quality is also heavily reliant on two other factors: cooking skills inherited from Java and cooking abilities learnt or acquired.

\section{Inherited Cooking Skills}

Javanese cuisine is well- known for its distinctive taste among the local population in Sabah. For Ibu Indang, her cooking skills inherited from her mother in Indonesia enabled her to cook traditional Javanese dishes such as opor, rojak, soto, tempe, gudek (jackfruit), lemper and carap ikan. These skills in fact had also been inherited not only by lbu Indang but by all the wives of the other respondents. It was therefore not surprising that the womenfolk assumed the role of 'taste quality controller' in their respective restaurants.

\section{Acquired Cooking Skills}

Beside inherited cooking skills, the ability to produce good food was also acquired from other sources. Pak Mokti would occasionally invite well-known chefs to give demonstrations and lessons for his cooks in aspects such as Western food menu items. This was to ensure that his establishments remained competitive and current. Pak Ismail and wife also learnt new recipes and kept abreast of current food trends through books and the Internet. In the case of Pak Ismail, Pak Yanto and Pak Rosli, their foray into the kitchen was based on their previous work experience in stalls and restaurants. Their wives also improved their cooking skills and acquired new recipes from the Internet such as tempe and tauhu. This was in addition to their existing skills inherited from their elders in Indonesia.

\section{Positive and Collective Values}

Positive values in life were also observed as anchor points in the respondents' survival as immigrants from the very beginning of their entry into Sabah.

\section{Positive Values}

The emphasis on positive values and optimism anchored on the teachings of Islam were used to guide the respondents' everyday lives and lifestyle. This was clearly demonstrated in the interviews with the respondents: Pak Mokti for instance held on to the belief of "... Don't look back! Look forward. If there is anyone yet to pay their debt... let it be... we are confident God Almighty will provide more for us in future". With a strong religious background, his sincerity was apparent; for him, belief in the workings of God and working hard to move forward was 
an important survival strategy. Pak Ismail also incorporated a similar positive principle by applying Islamic teachings as his way of life. According to him, "in business we need to be honest... there should not be any wrong doing! Anything that is not right will face heavy challenges... there is always misfortune or bad luck".

The same principle was similarly applied by Pak Mokti with his conviction that to operate a food business, the entrepreneur should believe that as long as he worked hard and obeyed God's precepts, the Almighty would bless him with abundance. Pak Mokti gave the example of an entrepreneur who at the height of success suddenly went bankrupt because he had started to forget the teachings of his religion and went against God's rules. Every business, according to Pak Mokti, must be clean to ensure more blessings in life. He was well- known for his religious wisdom and staunch principles, and had become a role model for his fellow businessmen such as Pak Ismail and Ibu Indang who considered him as someone who "banyak tahajudnya" ("prays a lot").

For Pak Yanto and Pak Rosli, their role models were the Chinese business owners in whose shops they had first started their food stall. Pak Rosli viewed the Chinese owners as hardworking and resilient since "the previous Chinese owner of this restaurant worked until old age... such diligence... I see him... and I feel motivated to work".

\section{Collective Spirit of Jemaah Tahlil}

The spirit of collectivism was also considered a pre-requisite towards ensuring the survival of the respondents in their adopted country. According to Pak Ismail, stiff competition in the food business in his hometown of Banyuwangi in Indonesia had created a high level of business jealousy which was considered part and parcel in the industry. In their drive to succeed, business rivals would at times purposely set out to destroy their competition. In contrast, this rivalry was not evident in Malaysia despite many Javanese from the homeland setting up business in the food industry. The collective spirit in fact was practised and very much nurtured among the food business community.

The weekly jemaah tahlil (collective prayer) activity held in rotation among the Javanese community was considered significant in creating this spirit of one-ness or shared values among them. The weekly activity provided a platform not only for community feasting but also social interaction and the sharing of views and experience among the business entrepreneurs, the majority being from the district of Malang in East Java. The prayer ceremony held during these meetings served as a cohesive bind among them and a motivating element to succeed in their business endeavours. Ibu Indang summed up this spirit of cohesiveness among the Javanese community in Sabah as "the Javanese is a strong link... when one is ill, or gets married, the community will come together. Prayer ceremonies would even go on for 40 days". It was therefore not surprising that the respondents viewed the majlis jemaah tahlil as a venue for strengthening their family links and at the same time fostering the networking element among them that could help ensure their survival as food business entrepreneurs in Sabah.

\section{Networking}

The struggle to set aside money as savings and acquire the necessary capital to start a business in Indonesia was attributed to the difficulty in securing jobs. Although 
there was no scarcity of food due to their family background as farmers where rice and vegetables were self- grown, finding money for everyday living was itself a constant challenge. The situation in Malaysia was markedly different: jobs as helpers in Javanese food stalls were easily available since the owners were inclined towards giving work opportunities to newcomers from their homeland. This initial experience subsequently influenced the way the newcomers would structure their lives. The sense of brotherhood and friendship nurtured in the respondents created numerous networking pathways that contributed towards their success and survival in the new country. It was through these series of networks with locals and fellow Indonesians that the respondents were able to expand their businesses. According to Pak Mokti, "...l once had 12 canteens at the same time... all of these were recommended by friends...they all knew me...".

\section{Citizenship Status}

Based on the respondents' responses on the issue of their success in the food business industry, it became apparent that their citizenship status was an important element. Their position as legal citizens of the country enabled them to deal more easily with various parties in matters such as banking, securing trading and vehicle licenses, approval from the local authorities, and acquiring business premises. As illustrated in Table 6, of the five respondents, only Pak Ismail was yet to succeed in changing his citizenship. This was not due to lack of trying: he in fact had applied several times to become a Malaysian citizen but failed. Business purposes aside, the respondents were certain that they would continue living in Sabah and spending the rest of their lives in the state with their family especially since their children had integrated into the local culture, language and lifestyle. As shared by Pak Mokti, his children were "orang Sabah" ("Sabah people").

\section{Courage, Commitment and Acceptance}

Lessons learnt from experience and the difficulties in life inculcated resilience. Since the respondents placed absolute trust in life being of God's design (tawakkal), they were seen as more accepting of whatever trials and tribulations that might occur. Pak Ismail who experienced hardship in his early days in Sabah and almost became a victim of human trafficking viewed the future without fear. This fearless nature made him into someone who did not easily give up or surrender before even trying. He shared, "I do not fear anything. The

Table 6 Citizenship Status

\begin{tabular}{cl}
\hline Employer & Citizenship Status \\
\hline Pak Yanto & Became a Malaysian citizen in the 1980s \\
Ibu Indang & Became a Malaysian citizen in the 1980s \\
Pak Rosli & Became a Malaysian citizen in the 1986 \\
Pak Ismail & Indonesian citizen (failed to obtain Malaysian \\
& citizenship several times) \\
Pak Mokti & Became a Malaysian citizen in the 1980s \\
\hline
\end{tabular}


important thing is that we must continue trying. This is destiny after all! The difficulties in life at the beginning were without doubt tough. It was during these times that [I had enough] of living in Malaysia but since coming to KK (Kota Kinabalu), life has become better. In fact it has become even more so since marriage ... that's destiny!".

The Islamic teachings applied in the everyday lives of the respondents did not include the word 'giving up'. In fact, effort and 'tawakkal' rendered their lives more meaningful. Pak Mokti, once the target of malicious intentions through 'black magic' objects sent to him, was certain that God's help would enable a man to live his life more courageously and fully accepting of his destiny. He stressed, "man does not know what his work will be tomorrow... or where God will place us... therefore we must believe, work hard and surrender". Apart from this absolute trust in God's plan, the respondents'success in life was also defined by sheer hard work, courage and faith.

\section{Conclusion}

Determination and the will to succeed were evident indicators for the positive survival of the Indonesian food business entrepreneurs. Community adaptation and assimilation, culture and local language also facilitated the process of survival in an adopted land; these were important elements in ensuring that there was unity and networking with fellow Indonesians as well as the local populace. The findings of this study demonstrated that the respondents' commitment in forging ahead in life was not at the expense of their spirituality. A life anchored on religious teachings was a universal value for the survival of immigrants whereby an absolute reliance on God and a steadfast belief to live life and do work according to how it might please the Almighty was practised by all the respondents.

The findings also shown that an important factor towards the creation of a harmonious organisation that is the employment relationship between the employer and his workers (Blyton \& Turnbull, 2004) as well as the level of accord (or discord) here would affect the strength of the workforce and the level of productivity in the survival of the respondents in foreign land. It can be seen that how workers form the integral assets of organisation (Abd. Aziz, 2002; Mondy et al., 2002; Storey, 2000); and it has been said that happy workers make for increased productivity in the organisation (Dessler, 2002). The relationship between employer and workers is critical in that it determines the employment relationship direction that the organisation wishes to establish as shown in the study.

Perhaps a point to be reiterated here is that not all immigrants become liabilities to their host countries. Several (such as Pak Mokti) had contributed towards developing the local community by building religious schools; others (all respondents) through their business ventures had bolstered the local economy. As shared by Pak Mokti, his children were "orang Sabah" ("Sabah people"). This statement echoes the findings of Halina (2004) who highlighted the integration strategy of Filipino immigrants in their acculturation of the local culture in Sabah. In the context of this study, positioning oneself on a level similar to the local people was an important move towards ensuring survival in a foreign land. Additionally, there is no doubt that their survival in the host country is determined from the very beginning by their commitment, tenacity and a steadfast belief in their destiny that made them survived. 


\section{Acknowledgements}

This successful completion of this study would not have been possible without the cooperation of Universiti Malaysia Sabah, the Indonesian Consulate Office in Sabah and the five respondents.

\section{References}

Ab Aziz Yusof. 2002. Pengurusan Sumber Manusia. Konsep, Isu dan Pelaksanaan. Petaling Jaya: Prentice Hall.

Anja Rudnick. 1996. Foreign Labour in Malaysian Manufacturing. Kuala Lumpur: INSAN.

Azizah Kassim. 2004. 'Illegal immigrants and the state in Sabah: Conflicting interests and the contest of will.' Kertas kerja dibentangkan di Closed Workshop on State Responses to the Presence and Employment of Foreign Workers in Sabah. Anjuran Unit Penyelidikan Pembangunan dan Etnografi, Sekolah Sains Sosial, Universiti Malaysia Sabah. 25 Februari.

Blyton, P. \& Turnbull, P. 2004. The Dynamic of Employee Relations. ( $3^{\text {rd }}$ ed.). Hampshire: Palgrave Macmillan.

Daud Amatzin 2004. 'Migrant Workers and the Plantation Sector'. Dalam Azizah Kassim (ed.) Proceedings of Seminar on Public Responses to Foregin Workers in Sabah. Kota Kinabalu: Universiti Malaysia Sabah.

Dayang Suria Mulia. 2009. 'Pekerja Asing di Sabah: Isu dan Perspektif.' Dalam Dzurizah Ibrahim et al. (pytg.). Hubungan Industri dan Sumber Manusia. Isu dan Perspektif. (Edisi Kedua). Kota Kinabalu: Universiti Malaysia.

Dessler, G. 2002. Pengurusan Sumber Manusia. (Edisi kelapan). Petaling Jaya: Prentice Hall.
Dzurizah Ibrahim \& Jalihah Md Shah. 2006. 'Buruh Kanak-kanak Asing: Dilema antara Tuntutan Kemanusian dengan Pembangunan Bandar'. Dalam Norhaslina Hassan (pytg.). Dinamika Masyarakat Bandar Malaysia. Kuala Lumpur: Universiti Malaya.

Dzurizah Ibrahim \& Jalihah Md Shah. 2014. Buruh Kanak-kanak di Sabah. Kota Kinabalu: Universiti Malaysia Sabah.

Jalihah Md Shah \& Ubong Imang. 2006. 'Imigran dan Pola Ekonomi Bandar: Kajian Kes di Bandar Raya Kota Kinabalu'. Dalam Norhaslina Hassan (pytg.). Dinamika Masyarakat Bandar Malaysia. Kuala Lumpur: Universiti Malaya.

James Gatidis. 2004. 'Recruitment and Hiring of Foreign Workers: Experience of Sawit Kinabalu Berhad.' Dalam Azizah Kassim (ed.) Proceedings of Seminar on Public Responses to Foregin Workers in Sabah. Kota Kinabalu: Universiti Malaysia Sabah.

Halina Sendera Mohd. Yakin. 2003. Akulturasi Imigran Filipina. Generasi Pertama dan Kedua di Sabah. Kota Kinabalu: Universiti Malaysia Sabah.

$\mathrm{Hj}$. Light Hj. Nanis. 2004. 'Foreign Workers: Problems and Prospects. Dalam Azizah Kassim (ed.) Proceedings of Seminar on Public Responses to Foregin Workers in Sabah. Kota Kinabalu: Universiti Malaysia Sabah.

Ho Ting Seng. 1989. 'International immigration in urban development: The case of the Filipino immigrants in Sabah'. Dalam Mohd Yaakub Hj. Johari \& Baldev S. Sidhu. (eds.). Urbanisation and Development: Prospects and Policies for Sabah Beyond 1990. Kota Kinabalu: Institute for Development Studies. Ismail Ali. 2008. 'Penglibatan dan sumbangan kanak-kanak warga Filipina dalam ekonomi perikanan di Sabah: Satu Pengadilan Moral?' Sosio Humanika. Vol. 1. No. 3. November. 
Mondy, R. W., Noe, R. M. \& Premeaux, S. R. 2002. Human Resource Management. (Eighth Ed.). New Jersey: Prentice Hall.

Ramli Dollah \& Mohd. Kamarulnizam Abdullah. 2015. 'Pembangunan Ekonomi dan Krisis Tenaga kerja Aing di Sabah'. Kertas kerja dibentangkan dalam Persidangan Malaysia-Indonesia ke-9. Jogjakarta, Indonesia.

Ramli Dollah, Fazli Abdul Hamid \& Rizal Zamani Idris. 2006. 'Perbandaran dan Jenayah dalam Kalangan Pendatang Asing di Kota Kinabalu'. Dalam Norhaslina Hassan (pytg.). Dinamika Masyarakat Bandar Malaysia. Kuala Lumpur: Universiti Malaya.

Storey, J. (2002). Managing Human Resources in the $21^{\text {st }}$ Century. New Delhi: Infinity Books.

Yap Pak Leong. 2004. 'Foreign Workers in Sabah: Views from East Malaysian Planters' Association (EMPA). Dalam Azizah Kassim (ed.) Proceedings of Seminar on Public Responses to Foregin Workers in Sabah. Kota Kinabalu: Universiti Malaysia Sabah. Zulkifly Hj. Mustapha. 1989. 'The role of the informal sector in urban development'. Dalam Mohd Yaakub Hj. Johari \& Baldev S. Sidhu. (eds.). Urbanisation and Development.: Prospects and Policies for Sabah Beyond 1990. Kota Kinabalu: Institute for Development Studies. 